Keywords:

Dickson quality index

Water retention

Nutrient absorption

Seedlings production

Historic:

Received 05/10/2017

Accepted I //12/2017

Palavras chave: Índice de qualidade de Dickson Retenção de água Absorção de nutrientes Produção de mudas

+Correspondence: erkonzen@gmail.com

DOI: | $0.1590 / 01047760201723042440$
Enéas Ricardo Konzen ${ }^{1+}$, Marcio Carlos Navroski', Gustavo Friederichs², Luís Henrique Ferrari', Mariane de Oliveira Pereira², Dionéia Felippe'

\section{THE USE OF HYDROGEL COMBINED WITH APPROPRIATE SUBSTRATE AND FERTILIZER IMPROVE QUALITY AND GROWTH PERFORMANCE OF Mimosa scabrella BENTH. SEEDLINGS}

ABSTRACT: Mimosa scabrella is a pioneer species that occurs mainly in the ombrophilous mixed forests of southern Brazil, assuming considerable economic relevance. As limited information is available concerning the most adequate substrates for producing seedlings of this species, we evaluated the combined effect of hydrogel with three types of substrates and four fertilizers in the initial growth and quality of seedlings of $M$. scabrella. The substrates were prepared with distinct proportions of a commercial organic substrate, vermiculite (VM) and pine bark (PB): I (70\% of TF, I0\% of VM and $20 \%$ of PB), 2 ( $40 \%$ of each TF and VM and $20 \%$ of $\mathrm{PB}$ ), and 3 ( $70 \%$ of TF, $10 \%$ of $\mathrm{VM}$ and $20 \%$ of $\mathrm{PB}$ ). The fertilizers consisted of a slow release formula (A), a traditional NPK (B), a compost of superphosphate and potassium chloride (C) and no fertilizer (D). The three soil mixtures were combined with each fertilizer in the presence or absence of hydrogel (factorial arrangement). The use of hydrogel promoted a positive effect on the growth of $M$. scabrella seedlings, probably by retaining more water and enabling increased nutrient absorption. In general, the polymer implicated in increased Dickson quality index (DQI). Additionally, the combination of organic compound and vermiculite in equilibrated proportions aid by pinus bark (substrate 2) were the best substrate. Finally, adding the fertilizers A or $B$ resulted in the best growth performance. In conclusion, the combined effect of hydrogel, substrate mixture and fertilizers improved the quality indexes of $M$. scabrella seedlings.

\section{O USO DE HIDROGEL COMBINADO COM SUBSTRATO E FERTILIZANTE ADEQUADOS MELHORAM A QUALIDADE E CRESCIMENTO DE MUDAS DE Mimosa scabrella BENTH.}

RESUMO: Mimosa scabrella é uma espécie pioneira que ocorre principalmente na floresta ombrófila mista do Sul do Brasil, apresentando considerável importância econômica. Considerando as limitadas informações acerca dos substratos mais adequados para a produção de mudas da espécie, neste trabalho avaliou-se o efeito combinado do uso de hidrogel com três tipos de substratos e quatro fertilizantes no crescimento inicial e qualidade de mudas de $M$. scabrella. Os substratos foram preparados com proporções distintas de um substrato orgânico comercial, vermiculita (VM) e casca de pinus (PB): I (70\% de TF, I0\% de VM e 20\% de PB), 2 ( $40 \%$ de TF e VM e $20 \%$ of PB), e 3 (70\% de TF, $10 \%$ de VM e $20 \%$ de PB). Os fertilizantes consistiram de uma fórmula de liberação lenta (A), o tradicional NPK (B), um composto de superfosfato simples e de cloreto de potássio (C) e com fertilizante ausente (D). Os três compostos de substratos foram combinados com cada fertilizante na presença ou ausência de hidrogel (arranjo fatorial). $O$ uso de hidrogel promoveu um efeito positivo no crescimento das mudas de $M$. scabrella, provavelmente retendo mais água e permitindo maior absorção de nutrientes. No geral, o polímero implicou em aumento no índice de qualidade de Dickson (DQI). Adicionalmente, a combinação do composto orgânico e vermiculita em proporções equilibradas adicionado de casca de pinus (substrato 2) constituíram o melhor substrato. A adição dos fertilizantes $A$ e $B$ resultaram na melhor performance de crescimento. Concluiu-se que a combinação de hidrogel com substrato composto e fertilizantes melhoraram os índices de qualidade de mudas de M. scabrella.

' University of the State of Santa Catarina - Lages, Santa Catarina, Brazil

2 Federal University of Paraná - Curitiba, Paraná, Brazil 


\section{INTRODUCTION}

Mimosa scabrella Benth. is a pioneer tree with short life cycle, which occurs mainly in the ombrophilous mixed forests in southern Brazil (southern distribution), but also in some areas of the Southeast region. In the country, it is popularly known as bracatinga, occurring in dense natural agglomerates and almost pure (CARPANEZZl et al., 1988; MAZUCHOWSKI et al., 20I4). In the southern region, it is naturally distributed in a continuous area between $23^{\circ} 50^{\prime}$ and $29^{\circ} 40$, from southern São Paulo to Rio Grande do Sul. It is more common in altitudes higher than 700 $\mathrm{m}$. The northern distribution of the species comprises discontinuous areas from southern São Paulo to Rio de Janeiro and Minas Gerais, limited to up to $21^{\circ} 30^{\prime}$ 'S (ROTTA and OLIVEIRA, 198I; CARPANEZZI et al., 1988).

M. scabrella reachs up to $20 \mathrm{~m}$ in height and a diameter at breast height up to $40 \mathrm{~cm}$ (CARPANEZZI et al., 1988). It assumes considerable economic importance, as its rotation cycle in plantations is between six and eight years (CARPANEZZI et al., 1997; KRATZ et al., 20I3). Its wood is mainly employed as a source of firewood and charcoal. It might as well be used for civil construction, ornamentation and recovery of disturbed areas (LORENZI, 2002). An interesting novel application concerns the honey produced by the bee Melipona marginata, which was proved to be originated exclusively from M. scabrella flowers and showed anti-inflammatory principles (BORSATO et al., 20I4).

Considering the application of $M$. scabrella in the market, it is important to produce high-quality seedlings, especially with reduced costs (KRATZ et al., 20I3). It starts with the collection of seeds from superior individuals, with desirable phenotypic features. One of the first challenges, however, is breaking the dormancy of the seeds, caused by the impermeability of the seed coat, which has been tested in a few studies (ROSA et al., 20I2; BARAZETTI and SCCOTI, 20I0).

For the production of seedlings, three main factors are among the ones to be considered, naming the substrate, fertilizers (type or doses) and type and size of the recipients for growing plants (WALKER et al., 20I I). Little has been done toward determining the most adequate substrates and fertilizers for the production of $M$. scabrella. One study addressed the effect of the combination between biosolid and carbonized rice hull at distinct proportions. However, the use of biosolid negatively influenced the development of $M$. scabrella seedlings (KRATZ et al., 2013). Another experiment showed that $180 \mathrm{~cm}^{3}$ tube containers combined with $6 \mathrm{~g} \cdot \mathrm{L}^{-1}$ of the fertilizer Osmocote ${ }^{\circledR}$ provided the best performance of $M$. scabrella seedlings growth among several treatments that were tested (STUPP et al. 20I5).

Another possibility for improving the production of seedlings from nurseries is the use of polymers such as hydrogels, which have the potential of increasing the efficiency of water use in the production of seedlings (NAVROSKl et al., 20I5). For example, the use of hydrogel enabled the reduction of irrigation and improved initial growth of seedlings of Eucalyptus dunnii (NAVROSKI et al., 20I5). When exposed to water deficit treatment, $E$. dunnii seedlings also showed delayed symptons of stress in seedlings cultivated with hydrogel (NAVROSKI et al., 2014). Similar results were obtained by Felippe et al. (2016) with E. benthamii. No report of the application of hydrogel-treatment has been documented yet for the production of $M$. scabrella seedlings.

In this study, we were aimed at analyzing the isolated and combined effects of the use of hydrogel (presence $\mathrm{x}$ absence), substrates (three types) and fertilizers (four types) in the initial growth performance of M. scabrella seedlings. We worked under the hypothesis that hydrogel increases water retention and, therefore, increases nutrient availability to the plants. Moreover, the combination of hydrogel with appropriate substrate and fertilizer improve the growth performance of bracatinga.

\section{MATERIAL AND METHODS}

\section{Location of the experiment and plant materials}

The experiment was conducted in Lages, Santa Catarina, Brazil. Lages is located at an altitude of 884 $\mathrm{m}$. According to Alvares et al. $(2013)$, the climate of the area is $C f b$, with an annual average precipitation of 1.483 $\mathrm{mm}$, average air relative humidity of $79.9 \%$, and average temperature of $15.6^{\circ} \mathrm{C}$. The experiment was installed in a greenhouse set up with automatic control of irrigation.

Seeds of $M$. scabrella were harvested from adult trees located at the Experimental Station of the Center of Agroveterinary Sciences, State University of Santa Catarina (CAV/UDESC). The seeds were soaked in hot water (at approximately $80^{\circ} \mathrm{C}$ ) and left in recipients for 12 hours before being sown. The seeds were directly sown in tube containers of $110 \mathrm{~cm}^{3}$ containing a mixture of substrate and fertilizer and supplemented or not with a waterproofing polymer (hydrogel) (Figure I).

\section{Treatments with hydrogel, substrates and fertilizers}

Three substrate compositions were tested in the experiment (Figure I), combining different proportions of Turfa Fértil ${ }^{\circledR}$ (TF), medium size vermiculite (VM) and 


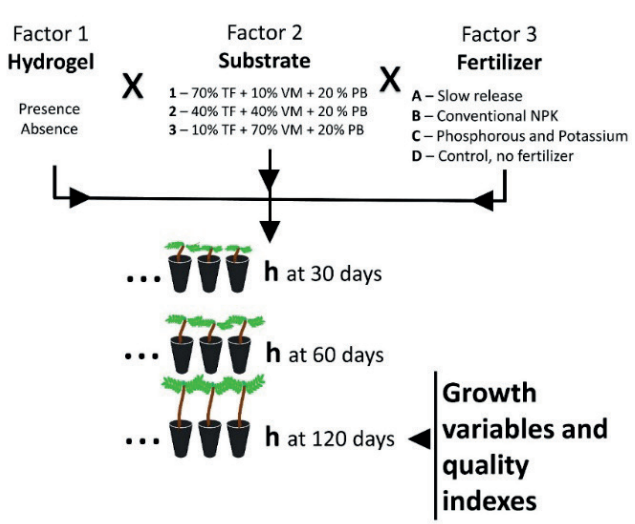

FIGURE I Treatments and their combinations as described by three factors and their respective levels, all applied to seedlings of Mimosa scabrella. in tube containers in greenhouse conditions for 120 days. TF: Turfa Fértil; VM: medium size vermiculite; PB: pinus decomposed bark.

decomposed pine bark (PB): (I) 70\% TF, 10\% VM and $20 \%$ PB; (2) $40 \%$ TF, $40 \%$ VM, 20\% PB; (3) $10 \%$ TF, $70 \% \mathrm{VM}$ and $20 \% \mathrm{~PB}$. Turfa Fértil is an organic compound with electric conductivity of $1.5( \pm 0.3) \mathrm{SM} \mathrm{cm} \mathrm{cm}^{-1}$, dry basic density of $280 \mathrm{~kg} \mathrm{~m}^{-3}, \mathrm{pH} 5.5$ ( \pm 0.5 ), maximum moisture of $55 \%$ and water retention capacity of $57 \%$, according to the manufacturer. Moreover, four types of fertilizers were combined with each substrate (Figure I). First, a fertilizer with slow release (NPK 19-06-10) at 6 $\mathrm{g} \cdot \mathrm{L}^{-1}(\mathrm{~A})$. The second consisted of a conventional formula of NPK (05-20-10) at $6 \mathrm{~g} \cdot \mathrm{L}^{-1}$ (B). A compost of simple superphosphate $\left(\mathrm{P}_{2} \mathrm{O}_{5} 18 \% \mathrm{Ca} 20 \%\right)$ and potassium chloride $\left(\mathrm{K}_{2} \mathrm{O} 42 \%\right)$ composed the third substrate, used at $6 \mathrm{~g} \cdot \mathrm{L}^{-1}(\mathrm{C})$. Finally, a control treatment (D) with no fertilizer was added.

The hydrogel was prepared with a commercial polymer, which consisted of a mixture of a copolymer of acrylamide $\left(\mathrm{C}_{3} \mathrm{H}_{5} \mathrm{NO}\right)$ and potassium acrylate $\left(\mathrm{K}_{2} \mathrm{~S}_{2} \mathrm{O}_{8}\right)$, used for absorbing and retaining high amounts of water and nutrients. The compost consisted of a white powder insoluble in water, with particles with sizes varying from 0.3 to $1.0 \mathrm{~mm}$, anionic, with $10 \%$ humidity, density of $0.8 \mathrm{~g} \mathrm{~cm}^{-3}$ and usage $\mathrm{pH}$ between 5 and 9 . The compost potentially makes available up to $95 \%$ of the solution stored for the plant and is capable of absorbing 300 times its mass in water and 100 times its volume (NAVROSKI et al., 20I5).

The preparation and mixing of the hydrogel to each substrate composition was performed according to Navroski et al. (20I5). The hydrogel was homogenized in small amounts of soil $\left(3 \mathrm{~g} \cdot \mathrm{L}^{-1}\right)$, according to each one of the treatment combinations (hydrogel $x$ substrate $x$ fertilizer). After mixing all components of each treatments, the tube containers were immediately filled with the substrate, especially those containing hydrogel. The tube containers were filled up to $80 \%$ of their capacity to avoid extravasation. The seeds of $M$. scabrella were immediately sown in the tube containers after those were filled with each substrate.

\section{Experimental design and response variables}

The experimental design was completely randomized with factorial arrangement with three factors $(2 \times 3 \times 4)$. The first factor consisted of the presence of hydrogel (presence or absence). The second was the type of substrate (levels I, 2 and 3 ) and the third was the fertilizer (levels A, B, C and D) (Figure I).

Measurements of the plant height $(H)$ of each seedling were taken at 30,60 and $I 20$ days after sowing the seeds. At the end of the experiment, we measured plant height $(H)$ and collar diameter (d). The plants were then harvested for determining the fresh weight of the shoot (SFW) and root (RFW). All samples were then placed in a drying oven at $60^{\circ} \mathrm{C}$ until constant weight. The dry weights of the shoot (SDW) and of the root (RDW) were recorded and the total dry weight was determined (TDW). From the dry and fresh weights were estimated the moisture content of the shoot (SM) and of the root (RM). By dividing the SDW and the RDW to the TDW, we determined the percentage of the shoot dry weight (PSDW) and of the root dry weight (PRDW) to the total dry weight. As quality indexes, the plant height and the collar diameter were divided to determine the height to diameter ratio $(H / d)$. Finally, the Dickson Quality Index (DQI) was estimated from the expression DQI = TDW $(\mathrm{g}) /[(\mathrm{H}(\mathrm{cm}) / \mathrm{d}(\mathrm{mm}))$ $+(\mathrm{SDW}(\mathrm{g}) /$ RDW $(\mathrm{g}))]$ (DICKSON et al., 1960).

\section{Statistical analysis}

The data were submitted to normality test with Shapiro-Wilks's. The homogeneity of variances was tested with Bartlett's test. When necessary, the data were accordingly transformed with box cox test. After the tests, the data were submitted to analysis of variance (ANOVA) $(P<0.05)$, computing a statistical model to estimate the effects of each factor (hydrogel, substrate and fertilizer) and to check their possible interaction when combined. For significant differences from the ANOVA, we performed mean comparisons with Tukey's $(P<0.05)$. R package 'laercio' (SILVA, 20I I) was used for ANOVA and ExpDes (FERREIRA et al., 2013) for decomposing each factor and checking the effects of their interaction. The Spearman correlation coefficient was determined among all variables, using the computational package PAST (HAMMER et al., 200I). 


\section{RESULTS}

\section{Variation of plant height over time}

The substrates and fertilizers interfered with the average $\mathrm{H}$ of $M$. scabrella. The highest plants were grown from substrate 2 (40\% TF, 40\% VM, 20\% PB) and fertilizers $A$ (fertilizer with slow release at $6 \mathrm{~g} \mathrm{~L}^{-1}$ ) and $B$ (conventional NPK) (Table I). However, these results varied according to the combination between substrate and fertilizer (Figure 2).

The most significant effect on $\mathrm{H}$, however, was the use of the hydrogel. Significantly higher $\mathrm{H}$ was showed by seedlings grown in substrates containing hydrogel (Table I). The Figure 2 demonstrates the difference between the substrates containing hydrogel and without the polymer, showing much higher values of plant height in those treated with the polymer. The differences between the seedlings grown with and those without hydrogel were evident even after the first 30 days after sowing, being even more prominent after 60 and 120 days.

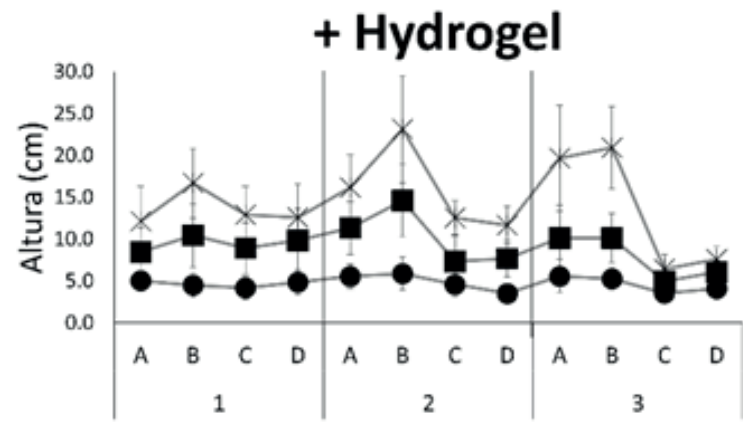

-30 d-Hydrogel -60 d-Hydrogel $\quad$ - $120 \mathrm{~d}$-Hydrogel

\section{- Hydrogel}

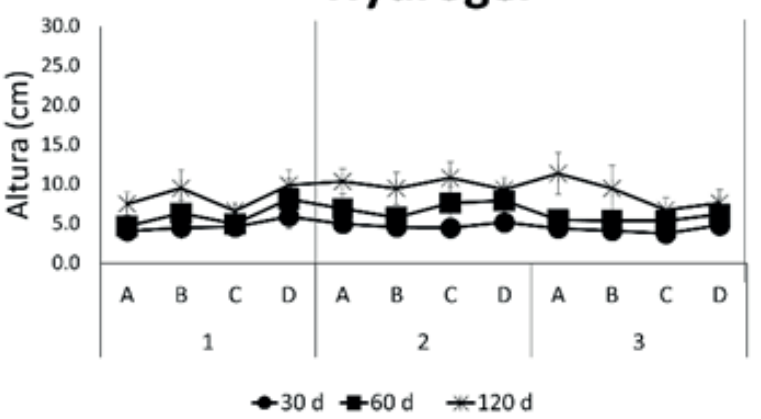

FIGURE 2 Average plant height $(\mathrm{cm})$ of Mimosa scabrella seedlings from different treatment-combinations (use of hydrogel $x$ type of substrate $x$ fertilizer). Bars represent the standard deviation of the measurements. Substrates: I - 70\% Turfa Fértil (TF), 10\% Vermiculite (VM) and $20 \%$ pine bark (PB); 2 - 40\% TF, $40 \%$ VM, 20\% PB; and $3-10 \%$ TF, $70 \%$ VM and $20 \%$ PB. Fertilizers: A - Slow release formula at 6 g.L-I; B - Conventional NPK (05-20-10) at 6 g.L-I; C - Compost of simple superphosphate; D - Control, without fertilizer.
TABLE I Average height $(\mathrm{cm})$ of Mimosa scabrella seedlings from different treatment-combinations (use of hydrogel $x$ type of substrate $x$ fertilizer) through the time period (days). Mean plant heights are presented separated by the levels within each treatment.

\begin{tabular}{ccccc}
\hline Factor & \multicolumn{4}{c}{ Mean plant height $(\mathrm{cm})$} \\
\hline Hydrogel & Absent & Present & \\
\hline Days after planting & $6.6 \mathrm{~b}^{*}$ & $9.4 \mathrm{a}$ & \\
& 30 days & 60 days & 120 days \\
& $4.7 \mathrm{c}$ & $7.7 \mathrm{~b}$ & $11.8 \mathrm{a}$ & \\
\hline Substrate & $\mathrm{I}$ & 2 & 3 & \\
& $7.7 \mathrm{~b}$ & $8.9 \mathrm{a}$ & $7.5 \mathrm{~b}$ & \\
\hline Fertilizer & $\mathrm{A}$ & $\mathrm{B}$ & $\mathrm{C}$ & $\mathrm{D}$ \\
& $8.6 \mathrm{~b}$ & $9.5 \mathrm{a}$ & $6.6 \mathrm{~d}$ & $7.3 \mathrm{c}$ \\
\hline
\end{tabular}

*Different letters among treatments represent significant differences based on Tukey's $(P<0.05)$ within each level of each factor. For example, the hydrogel factor has only two levels, absent or present, and the overall mean for each treatment are compared.

\section{Statistical significance of growth variables and quality indexes}

An overall ANOVA revealed that the incorporation of hydrogel to the substrate significantly altered $(P<0.05)$ the shoot fresh weight (SFW) and dry weight (SDW), as well as plant height $(H)$, collar diameter $(d)$, the $H / d$ ratio, the proportions of the shoot (PSDW) and root (PRDW) dry weights to the total and the Dickson quality index (DQI) (Tables 2 and 3). However, significant interaction effect ( $P$ $<0.05)$ was detected with the combination of the polymer with the substrates and fertilizers for the total dry weight and the moisture content of the shoot (interaction of the three factors), implicating that each factor concurred to shape the final magnitude measured for each of them (Tables 2 and 3 ).

An overall ANOVA of the substrate and fertilizer effects also demonstrated significant variation among the levels within each factor for some of the variables. The fertilizer did not significantly alter only the root fresh weight and root dry weight, when all data were analyzed together. The combination of the substrates with the fertilizers also interacted in the results for shoot fresh weight (SFW), root fresh weight (RFW), shoot dry weight (SDW), plant height $(H)$, collar diameter $(d)$ and the quality indexes $H / d$ and Dickson Quality Index (DQI).

Highlighting only the quality indexes, the use of hydrogel and the fertilizers contributed separately and significantly for altering $D Q I$, while the substrate promoted no significant change in the index. However, significant interaction has been detected between the factors hydrogel and substrate, as well as between hydrogel and the fertilizers for $D Q I$.

\section{Effect of the use of hydrogel on the growth and biomass variables and quality}

By examining the whole set of data, the use of hydrogel clearly implicated in a better performance of 
TABLE 2 Probability of significance for each treatment and their combinations for growth variables of seedlings of Mimosa scabrella. H: hydrogel; S: substrate (soil); F: fertilizer; $\mathrm{H} \times \mathrm{S}, \mathrm{H} \times \mathrm{F}, \mathrm{S} \times \mathrm{F}, \mathrm{H} \times \mathrm{S} \times \mathrm{F}$ : factorial combinations..

\begin{tabular}{|c|c|c|c|c|c|c|c|c|c|}
\hline Factor & SFW & RFW & SDW & RDW & TDW & SM & RM & $\mathrm{H}$ & $\mathrm{d}$ \\
\hline $\mathrm{H}$ & $<0.00$ I $^{*} * *$ & $0.095^{\mathrm{ns}}$ & $<0.001^{*} * * *$ & $0.377^{\text {ns }}$ & $0.448^{\text {ns }}$ & $0.448^{\mathrm{ns}}$ & $0.48 I^{\mathrm{ns}}$ & $<0.001^{* * * *}$ & $<0.00$ I $^{* * * * *}$ \\
\hline S & $0.674^{\mathrm{ns}}$ & $0.040^{*}$ & $0.77 I^{\text {ns }}$ & 0.249 ns & $0.490 \mathrm{~ns}$ & $0.490 \mathrm{~ns}$ & $0.138^{\mathrm{ns}}$ & $0.255^{\mathrm{ns}}$ & 0.292 ns \\
\hline $\mathrm{F}$ & $<0.001^{*} * * *$ & $0.205^{\mathrm{ns}}$ & $<0.001^{* * * *}$ & $0.312^{\mathrm{ns}}$ & $<0.00 I^{* * * *}$ & $<0.001^{* * * * *}$ & $0.005^{* * *}$ & $<0.001^{*} * * *$ & $<0.00 I^{* * * * *}$ \\
\hline $\mathrm{H} \times \mathrm{S}$ & $0.002 *$ * & $0.597^{\mathrm{ns}}$ & $0.006 * *$ & $0.286^{\mathrm{ns}}$ & 0.397 ns & 0.397 ns & $0.056^{\mathrm{ns}}$ & 0.477 ns & $0.011 *$ \\
\hline $\mathrm{H} \times \mathrm{F}$ & $0.005^{* *}$ & $0.00 I^{* *}$ & $0.004^{* *}$ & $0.00 I^{* *}$ & $0.003^{*} *$ & $0.003^{*} *$ & $0.03 I^{*}$ & $<0.00 I^{* * * *}$ & $<0.001^{* * * *}$ \\
\hline$S \times F$ & $<0.00 I^{* * * *}$ & $0.019 *$ & $<0.00 I^{* * * *}$ & $0.130^{\mathrm{ns}}$ & $0.398^{\mathrm{ns}}$ & $0.398^{\mathrm{ns}}$ & $0.803^{\mathrm{ns}}$ & $0.001 * *$ & $0.008^{*} *$ \\
\hline $\mathrm{H} \times \mathrm{S} \times \mathrm{F}$ & $0.053^{\mathrm{ns}}$ & $0.282^{n s}$ & $0.136^{\mathrm{ns}}$ & $0.27 I^{\text {ns }}$ & $0.00 I^{* * *}$ & $0.00 I^{* * *}$ & $0.704^{\text {ns }}$ & $0.176^{\mathrm{ns}}$ & $0.424^{\text {ns }}$ \\
\hline
\end{tabular}

ns: non-significant, *: significant at $\mathrm{P}<0.05$; **: significant at $\mathrm{P}<0.0 \mathrm{I}$; ***: significant at $\mathrm{P}<0.00 \mathrm{I}$. SFW (g): shoot fresh weight; RFW (g): root fresh weight; SDW (g): shoot dry weight; RDW (g): root dry weight; TDW (g): total dry weight; SM (\%): shoot moisture content; RM (\%): root moisture content; H (cm): plant height; $d$ $(\mathrm{mm})$ : root collar diameter.

TABLE 3 Probability of significance for each treatment and their combinations for quality indexes of seedlings of Mimosa scabrella. H: hydrogel; S: substrate (soil); F: fertilizer; $\mathrm{H}$ $\times \mathrm{S}, \mathrm{H} \times \mathrm{F}, \mathrm{S} \times \mathrm{F}, \mathrm{H} \times \mathrm{S} \times \mathrm{F}$ : factorial combinations.

\begin{tabular}{|c|c|c|c|c|}
\hline Factors & $\mathrm{H} / \mathrm{d}$ & PSDW & PRDW & DQI \\
\hline $\mathrm{H}$ & $<0.00 I^{*} * * *$ & $<0.00 I^{*} * * *$ & $<0.00$ I**** & $0.002 * *$ \\
\hline$S$ & $0.601 \mathrm{~ns}$ & $0.025 *$ & $0.035^{*}$ & 0.522 ns \\
\hline$F$ & $<0.00 I^{* * * *}$ & $<0.00 I^{* * * *}$ & $<0.001 * * * *$ & $<0.00 I^{* * * *}$ \\
\hline $\mathrm{H} \times \mathrm{S}$ & $0.317^{\mathrm{ns}}$ & $0.14 I^{\text {ns }}$ & $0.147 \mathrm{~ns}$ & $0.047^{*}$ \\
\hline $\mathrm{H} \times \mathrm{F}$ & 0.423 ns & $0.022^{*}$ & $0.03 I^{*}$ & $<0.001 * * *$ \\
\hline$S \times F$ & $0.036 *$ & 0.832 ns & 0.802 ns & $0.007 * *$ \\
\hline $\mathrm{H} \times \mathrm{S} \times \mathrm{F}$ & 0.078 ns & $0.193^{\mathrm{ns}}$ & $0.223 \mathrm{~ns}$ & $0.184^{\mathrm{ns}}$ \\
\hline
\end{tabular}

ns: non-significant, *: significant at $\mathrm{P}<0.05$; ** significant at $\mathrm{P}<0,01$; ***: significant at $\mathrm{P}<0.00 \mathrm{I} . \mathrm{H} / \mathrm{d}(\mathrm{cm} / \mathrm{mm})$ : proportion of plant height to root collar diameter; PSDW (\%): proportion of the shoot dry weight to the total; PRDW (\%): proportion of the root dry weight to the total; DQI: Dickson quality index.

both the growth/biomass variables (Tables 4 and 5 ) and the quality indexes (Table 6). Analyzing the dry weights, the overall SDW mean was more than two times (2.2) higher when hydrogel was employed $(0.30 \mathrm{I} \mathrm{g}$ with hydrogel and $0.137 \mathrm{~g}$ with no hydrogel). The RDW of the plants was also around I $50 \%$ higher in those grown with hydrogel $(0.189 \mathrm{~g}$ with hydrogel and $0.126 \mathrm{~g}$ without hydrogel). It resulted in a similar finding for the TDW, I.86 times higher for the hydrogel-treated substrates ( $0.490 \mathrm{~g}$ with hydrogel and $0.263 \mathrm{~g}$ without hydrogel).

The overall mean of plant height of $M$. scabrella seedlings cultivated in hydrogel-treated substrates ( 16.8 $\mathrm{cm}$ ) (Table 5) was 1.6 times higher than those in which no polymer was added $(10.6 \mathrm{~cm})($ Table 4$)$. Similarly, the collar diameter was 1.4 times higher in polymer-treated plants ( $1.44 \mathrm{~mm}$ ).

As a result of the combination of the aforementioned variables, the $D Q I$ of the plants was considerably higher when the substrates were aid by hydrogel $(0.035)$, as revealed by the significant results achieved from ANOVA $(P<0.05)$ (Table 3).

Another important result of this work concerns the proportion of biomass allocated to the shoot (PSDW) and root (PRDW) of the M. scabrella seedlings. When the polymer was added to the substrates, the difference between the PSDW and PRDW was increased, contributing with 65.7 and $34.3 \%$, respectively, of the mean total biomass (Table 5). In the absence of the polymer, those values were 55.9 and $44.1 \%$, respectively. Therefore, the use of hydrogel increased the shoot biomass proportion to the total (Table 5).

\section{Effects of the substrates and the fertilizers}

An analysis of the effects of the substrates and fertilizers and their combination is presented on Tables 4, 5 and 6. Mean comparisons within the tables are based on Tukey's test and were presented only for the combination between substrates and fertilizers. Therefore, the difference attributed to the use of hydrogel was not indicated in the tables.

In general, substrate 2 (40\% TF, 40\% VM, 20\% PB) implicated in the best performance of the growth variables. It is noteworthy that the total biomass of plants grown with this substrate $(T D W=0.309 \mathrm{~g}$ when no hydrogel was used, and $T D W=0.554 \mathrm{~g}$ with substrates aid by the polymer) was the highest among all the three tested (Tables 4 and 5 ). The highest $H$ and $d$ were also measured in plants treated with substrate $2(H=11.7 \mathrm{~cm}$ and $d=1.1 \mathrm{~mm}$ with no hydrogel; and $H=19 \mathrm{~cm}$ and $d=1.6 \mathrm{~mm}$ in hydrogeltreated substrates) (Tables 4 and 5). As for the quality index $D Q I$, it was only higher when the substrate 2 was combined with the use of hydrogel $(D Q I=0.039)$. In the absence of the polymer, substrate 3 implicated in the highest quality values $(D Q I=0.038)$ (Table 6).

The combination of the substrates with the fertilizers promoted responses that varied according to the variable analyzed. Frequently, no significant differences were detected (Tukey's, $P<0.05$ ) among the fertilizers combined with the substrates but without hydrogel. When hydrogel was applied to the substrates, however, plants grown with the application of the fertilizers $A$ and $B$ presented the best performances (we highlight variables such as $H, d, T D W$ ). The use of hydrogel also implicated in better $D Q I$ for plants grown with fertilizers $A$ and $B$, however, interaction between substrate and fertilizer also interfered with the results (Table 5). 
TABLE 4 Summary of biomass and growth variables of Mimosa scabrella seedlings under distinct treatment-combinations (substrate $\mathrm{x}$ fertilizer) when no hydrogel was used.

\begin{tabular}{|c|c|c|c|c|c|c|}
\hline & & & & Fertilizer & & \\
\hline & Substrate & $\mathrm{A}$ & $B$ & C & $D$ & Mean \\
\hline \multirow[t]{4}{*}{ SFW (g) } & $\mathrm{I}$ & $0.31 \mathrm{I} \mathrm{aB}$ & $0.609 \mathrm{aA}$ & $0.200 \mathrm{aB}$ & $0.436 \mathrm{aA}$ & 0.389 \\
\hline & 2 & $0.567 \mathrm{aB}$ & $0.695 \mathrm{aA}$ & $0.695 \mathrm{aA}$ & $0.425 \mathrm{aA}$ & 0.595 \\
\hline & 3 & $1.141 \mathrm{aA}$ & $0.607 \mathrm{bA}$ & $0.298 \mathrm{bAB}$ & $0.346 \mathrm{bA}$ & 0.598 \\
\hline & Mean & 0.673 & 0.637 & 0.398 & 0.402 & - \\
\hline \multirow[t]{4}{*}{ RFW (g) } & I & 0.422 & 0.584 & 0.799 & 1.26 & $0.766 \mathrm{~A}$ \\
\hline & 2 & 1.052 & 0.815 & 1.297 & 1.657 & $1.205 \mathrm{~A}$ \\
\hline & 3 & 1.4 & 0.837 & 0.836 & 1.913 & $1.247 \mathrm{~A}$ \\
\hline & Mean & $0.958 \mathrm{~b}$ & $0.745 \mathrm{~b}$ & $0.977 \mathrm{~b}$ & $1.610 \mathrm{a}$ & - \\
\hline \multirow{4}{*}{ SDW $(g)$} & 1 & $0.084 \mathrm{aB}$ & $0.144 \mathrm{aA}$ & $0.055 \mathrm{aB}$ & $0.118 \mathrm{aA}$ & 0.1 \\
\hline & 2 & $0.154 \mathrm{aB}$ & $0.173 \mathrm{aA}$ & $0.187 \mathrm{aA}$ & $0.124 \mathrm{aA}$ & 0.159 \\
\hline & 3 & $0.271 \mathrm{aA}$ & $0.156 \mathrm{abA}$ & $0.073 \mathrm{bB}$ & $0.108 \mathrm{bA}$ & 0.152 \\
\hline & Mean & 0.17 & 0.158 & 0.105 & 0.117 & \\
\hline \multirow[t]{4}{*}{ RDW (g) } & I & 0.051 & 0.067 & 0.069 & 0.138 & $0.081 \mathrm{~A}$ \\
\hline & 2 & 0.171 & 0.071 & 0.147 & 0.208 & $0.149 \mathrm{~A}$ \\
\hline & 3 & 0.172 & 0.095 & 0.088 & 0.238 & $0.148 \mathrm{~A}$ \\
\hline & Mean & $0.131 \mathrm{ab}$ & $0.078 \mathrm{~b}$ & $0.101 \mathrm{~b}$ & $0.194 \mathrm{a}$ & - \\
\hline \multirow[t]{4}{*}{ TDW (g) } & I & 0.135 & 0.211 & 0.124 & 0.256 & $0.182 \mathrm{~B}$ \\
\hline & 2 & 0.325 & 0.243 & 0.334 & 0.332 & $0.309 \mathrm{~A}$ \\
\hline & 3 & 0.443 & 0.251 & 0.16 & 0.345 & $0.300 \mathrm{~A}$ \\
\hline & Mean & $0.30 \mathrm{I} \mathrm{a}$ & $0.235 \mathrm{a}$ & $0.206 \mathrm{a}$ & $0.311 \mathrm{a}$ & - \\
\hline \multirow[t]{4}{*}{ SM (\%) } & I & $27.33 \mathrm{aA}$ & $23.18 \mathrm{bA}$ & $27.15 \mathrm{aA}$ & $27.22 \mathrm{aB}$ & 26.221 \\
\hline & 2 & $27.114 \mathrm{abA}$ & $24.621 \mathrm{bA}$ & $25.224 \mathrm{bA}$ & $29.769 \mathrm{aAB}$ & 26.682 \\
\hline & 3 & 23.992 bA & $25.132 \mathrm{bA}$ & 24.601 bA & $30.789 \mathrm{aA}$ & 26.128 \\
\hline & Mean & 26.145 & 24.311 & 25.659 & 29.26 & - \\
\hline \multirow[t]{4}{*}{ RM (\%) } & I & 11.68 & 10.76 & 8.6 & 10.45 & $10.372 \mathrm{~A}$ \\
\hline & 2 & 15.362 & 8.915 & 10.029 & 11.718 & II. $506 \mathrm{~A}$ \\
\hline & 3 & 11.165 & 10.045 & 9.916 & 11.655 & $10.695 \mathrm{~A}$ \\
\hline & Mean & $12.737 \mathrm{a}$ & $9.906 \mathrm{~b}$ & $9.5 \mathrm{I} 4 \mathrm{~b}$ & $11.273 \mathrm{ab}$ & - \\
\hline \multirow[t]{4}{*}{$\mathrm{H}(\mathrm{cm})$} & I & 9.4 & 11.4 & 8 & 11.2 & $9.995 \mathrm{~A}$ \\
\hline & 2 & 12.8 & 10.8 & 12 & 11.3 & II.720 A \\
\hline & 3 & 13.4 & 10.6 & 7.8 & 8.2 & $9.998 \mathrm{~A}$ \\
\hline & Mean & $11.867 \mathrm{a}$ & $10.920 \mathrm{a}$ & $9.280 \mathrm{a}$ & $10.217 \mathrm{a}$ & - \\
\hline \multirow[t]{4}{*}{$\mathrm{d}(\mathrm{mm})$} & 1 & 0.918 & 1.052 & 0.888 & 1.164 & $1.006 \mathrm{~A}$ \\
\hline & 2 & 1.056 & 1.028 & 1.18 & 1.106 & $1.093 \mathrm{~A}$ \\
\hline & 3 & 1.234 & 1.058 & 0.962 & 1.04 & $1.074 \mathrm{~A}$ \\
\hline & Mean & $1.069 \mathrm{a}$ & $1.046 \mathrm{a}$ & $1.010 \mathrm{a}$ & $1.103 \mathrm{a}$ & - \\
\hline
\end{tabular}

Substrates: I - 70\% Turfa Fértil (TF), 10\% Vermiculite (VM) and 20\% pine bark (PB); 2 - 40\% TF, 40\% VM, 20\% PB; and 3 - 10\% TF, 70\% VM and 20\% PB. Fertilizers: A - Slow release formula at $6 \mathrm{~g} \cdot \mathrm{L}^{-1}$; B - Conventional NPK (05-20-10) at $6 \mathrm{~g} \cdot \mathrm{L}^{-1}$; C - Compost of simple superphosphate; D - Control, without fertilizer. SFW (g): shoot fresh weight; RFW (g): root fresh weight; SDW (g): shoot dry weight; RDW (g): root dry weight; TDW (g): total dry weight; SM (\%): shoot moisture content; $\mathrm{RM}(\%)$ : root moisture content; $\mathrm{H}(\mathrm{cm})$ : plant height; $\mathrm{d}(\mathrm{mm})$ : root collar diameter. Different capital letters indicate significant differences $(\mathrm{P}<0.05)$ in columns, while different lowercase letters indicated differences in lines.

\section{Correlation among the variables}

Among all variables, here we highlighted $D Q I$ and its correlation with the other variables examined (Table 7). High and positive Spearman correlation coefficients (over 0.7 ) were found between $D Q I$ and RFW, RDW and $P R D W$. Moderate levels ( 0.4 to 0.7$)$ of correlation were found between $D Q I$ and SFW, SDW, SM, RM and $H$.

\section{DISCUSSION}

\section{Height and collar diameter M. scabrella seedlings with the use of hydrogel}

The use of hydrogel had a major effect on the growth of $M$. scabrella seedlings, as observed first with plant height after 30, 60 and I 20 days, and also with the final measurements of collar diameter. The combination of hydrogel with the substrate 2 and, mainly, fertilizers $A$ and $B$ implicated in the best performance of growth as well. Similar results have also been presented by other studies with forest tree species. For example, a positive influence of hydrogel combined with distinct doses of urea on $H$ and $d$ were detected in an experiment conducted with seedlings of Handroanthus ochraceus (Bignoniaceae), a widely distributed species with ornamental, ecological and economical significance in Brazil (MEWS et al., 20I5). The application of $6 \mathrm{~g} \cdot \mathrm{L}^{-1}$ of hydrogel in substrates for growing seedlings of Corymbia citriodora increased plant height and diameter in $23 \%$ (BERNARDI et al., 20I2) However, a regression analysis with doses of hydrogel varying from 0 to $6 \mathrm{~g} \cdot \mathrm{L}^{-1}$ revealed a quadratic behavior of $\mathrm{H}$ for seedlings of Eucalyptus dunnii 
TABLE 5 Summary of biomass and growth variables of Mimosa scabrella seedlings under distinct treatmentcombinations (substrate $x$ fertilizer) when hydrogel was applied.

\begin{tabular}{|c|c|c|c|c|c|}
\hline & \multicolumn{5}{|c|}{ Fertilizer } \\
\hline & $A$ & $B$ & $C$ & $\mathrm{D}$ & Mean \\
\hline \multirow[t]{3}{*}{ SFW (g) } & $0.896 \mathrm{aB}$ & $1.499 \mathrm{aA}$ & $0.774 \mathrm{aA}$ & $0.682 \mathrm{aA}$ & 0.963 \\
\hline & I.557 abAB & $2.288 \mathrm{aA}$ & 0.864 bA & $0.682 \mathrm{bA}$ & 1.348 \\
\hline & $2.180 \mathrm{aA}$ & $\mathrm{I} .770 \mathrm{aA}$ & $0.169 \mathrm{bA}$ & $0.181 \mathrm{bA}$ & 1.075 \\
\hline Mean & 1.544 & 1.853 & 0.602 & 0.515 & - \\
\hline \multirow[t]{3}{*}{ RFW (g) } & $0.768 \mathrm{aB}$ & $\mathrm{I} .247 \mathrm{aA}$ & $0.746 \mathrm{aA}$ & $1.315 \mathrm{aA}$ & 1.019 \\
\hline & I.264 aB & $2.300 \mathrm{aA}$ & $1.668 \mathrm{aA}$ & $1.359 \mathrm{aA}$ & 1.648 \\
\hline & $4.122 \mathrm{aA}$ & $2.946 \mathrm{aA}$ & $0.613 \mathrm{bA}$ & $0.585 \mathrm{bA}$ & 2.066 \\
\hline Mean & 2.052 & 2.164 & 1.009 & 1.086 & - \\
\hline \multirow[t]{3}{*}{ SDW (g) } & $0.232 \mathrm{aB}$ & $0.387 \mathrm{aA}$ & $0.202 \mathrm{aA}$ & $0.192 \mathrm{aA}$ & 0.253 \\
\hline & $0.4 I I \mathrm{ab} A B$ & $0.638 \mathrm{aA}$ & $0.254 \mathrm{bA}$ & $0.179 \mathrm{bA}$ & 0.37 \\
\hline & $0.599 \mathrm{aA}$ & $0.419 \mathrm{aA}$ & $0.049 \mathrm{bA}$ & $0.049 \mathrm{bA}$ & 0.279 \\
\hline Mean & 0.414 & 0.482 & 0.169 & 0.14 & - \\
\hline \multirow[t]{3}{*}{ RDW (g) } & 0.118 & 0.141 & 0.107 & 0.179 & $0.136 \mathrm{~A}$ \\
\hline & 0.152 & 0.261 & 0.224 & 0.098 & $0.184 \mathrm{~A}$ \\
\hline & 0.596 & 0.287 & 0.071 & 0.038 & $0.248 \mathrm{~A}$ \\
\hline Mean & $0.289 \mathrm{a}$ & $0.230 \mathrm{a}$ & $0.134 a$ & $0.105 \mathrm{a}$ & - \\
\hline \multirow[t]{3}{*}{ TDW (g) } & $0.349 \mathrm{aB}$ & $0.529 \mathrm{aA}$ & $0.309 \mathrm{aA}$ & $0.37 \mathrm{I} a \mathrm{~A}$ & 0.39 \\
\hline & $0.563 \mathrm{aB}$ & $0.898 \mathrm{aA}$ & $0.478 \mathrm{aA}$ & $0.277 \mathrm{aA}$ & 0.554 \\
\hline & $1.195 \mathrm{aA}$ & $0.706 \mathrm{abA}$ & $0.120 \mathrm{bA}$ & $0.087 \mathrm{bA}$ & 0.527 \\
\hline Mean & 0.702 & $0.71 \mathrm{I}$ & 0.303 & 0.245 & - \\
\hline \multirow[t]{2}{*}{ SM (\%) } & 25.5 & 25.661 & 25.505 & 27.615 & $26.071 \mathrm{~A}$ \\
\hline & $\begin{array}{l}25.935 \\
26.618\end{array}$ & $\begin{array}{c}27.08 \\
24.891\end{array}$ & $\begin{array}{l}28.714 \\
29.135\end{array}$ & $\begin{array}{l}26.605 \\
26.92\end{array}$ & $\begin{array}{l}27.083 \mathrm{~A} \\
26.891 \mathrm{~A}\end{array}$ \\
\hline Mean & $26.018 \mathrm{a}$ & $25.877 \mathrm{a}$ & $27.784 \mathrm{a}$ & $27.047 \mathrm{a}$ & - \\
\hline \multirow[t]{3}{*}{ RM (\%) } & 14.462 & 10.7 & 12.268 & 10.873 & $12.076 \mathrm{~A}$ \\
\hline & II. 424 & 10.315 & 10.649 & 6.377 & $9.691 \mathrm{~A}$ \\
\hline & 11.049 & 9.448 & 10.995 & 6.521 & $9.503 \mathrm{~A}$ \\
\hline Mean & $12.312 \mathrm{a}$ & $10.154 \mathrm{ab}$ & II.304 ab & $7.923 \mathrm{~b}$ & - \\
\hline \multirow[t]{3}{*}{$\mathrm{H}(\mathrm{cm})$} & $17.2 \mathrm{aA}$ & $19.1 \mathrm{aB}$ & I4.I aA & $14.0 \mathrm{aA}$ & 16.09 \\
\hline & $20.2 \mathrm{bA}$ & $28.7 \mathrm{aA}$ & $13.8 \mathrm{aA}$ & $13.3 \mathrm{aA}$ & 18.98 \\
\hline & $21.9 \mathrm{aA}$ & $23.3 \mathrm{aAB}$ & $7.4 \mathrm{bA}$ & $9.0 \mathrm{bA}$ & 15.4 \\
\hline Mean & 19.767 & 23.7 & 11.753 & 12.073 & - \\
\hline \multirow[t]{3}{*}{$\mathrm{d}(\mathrm{mm})$} & 1.304 & 1.82 & 1.274 & 1.266 & $1.416 \mathrm{AB}$ \\
\hline & 1.65 & 2.12 & I.344 & 1.37 & $1.621 \mathrm{~A}$ \\
\hline & 1.694 & 1.768 & 0.86 & 0.814 & I.284 B \\
\hline Mean & $1.549 \mathrm{~b}$ & $1.903 \mathrm{a}$ & $1.159 c$ & $1.150 \mathrm{c}$ & - \\
\hline
\end{tabular}

Substrates: I - 70\% Turfa Fértil (TF), 10\% Vermiculite (VM) and $20 \%$ pine bark (PB); 2 - 40\% TF, $40 \%$ VM, 20\% PB; and $3-10 \%$ TF, $70 \%$ VM and $20 \%$ PB. Fertilizers: A - Slow release formula at 6 g.L-I; B - Conventional NPK (05-20-10) at $6 \mathrm{~g}$.L-I; C - Compost of simple superphosphate; D - Control, without fertilizer. SFW (g): shoot fresh weight; RFW (g): root fresh weight; SDW (g): shoot dry weight; RDW (g): root dry weight; TDW (g): total dry weight; SM (\%): shoot moisture content; $\mathrm{RM}(\%)$ : root moisture content; $\mathrm{H}(\mathrm{cm})$ : plant height; $\mathrm{d}(\mathrm{mm})$ : root collar diameter. Different capital letters indicate significant differences $(\mathrm{P}<$ 0.05 ) in columns, while different lowercase letters indicated differences in lines.

(NAVROSKI et al., 20I4), suggesting that doses higher than $6 \mathrm{~g} \cdot \mathrm{L}^{-1}$ might lead to a diminished growth in height. In fact, Sarvas et al. (2007) showed that the application of $7 \mathrm{~g}$ of hydrogel per planting hole in a recovered area with Pinus sylvestris led to overdosage and plant mortality. In our study, we used the concentration of $3{\mathrm{~g} \cdot \mathrm{L}^{-1}}$ as for the presence of the polymer. Further experiments aimed at testing concentrations of hydrogel and their effect on M. scabrella growth would be required to better acknowledge the beneficial effects and the limits of the dosages that can be used of this polymer.

Similar to the influence on plant height and diameter, the use of hydrogel resulted in higher accumulation of biomass in the seedlings of $M$. scabrella. By extension, analogous results were obtained for seedlings of $H$. ochraceus examined by Mews et al. (20I5). The combination between hydrogel and urea in that study, however, concurred for distinct performances. For the highest shoot biomass (SDW) the concentration of hydrogel was of $2 \mathrm{~g}^{\mathrm{L}} \mathrm{L}^{-1}$, while the highest root biomass was achieved with I $\mathrm{g} \cdot \mathrm{L}^{-1}$ of the polymer. For a quality variable used by the authors, the proportion of the root biomass to the shoot biomass, the concentration of $4 \mathrm{~g}$. $\mathrm{L}^{-1}$ resulted in the highest average values. Lastly, I g. $\mathrm{L}^{-1}$ of hydrogel resulted in the best Dickson quality index values for $H$. ochraceus, revealing that for this species, lower quantities of the polymer implicated in higher seedling quality (MEWS et al., 20I5). Although having determined other quality indexes, here we emphasize the $D Q I$ as it has been indicated as one of the most reliable indexes for seedlings quality. Normally, as high as its value is, higher is the quality of the plant (GOMES, 2002). In our work, the use of $3 \mathrm{~g} \cdot \mathrm{L}^{-1}$ greatly improved the $D Q I$ in comparison to the control treatment (without hydrogel) (Table 6). We reinforce, however, that a dose-dependent test would be needed to verify the optimal concentration for the production of high-quality seedlings of $M$. scabrella.

The improved performance of growth and quality of the seedlings of M. scabrella in this study based on the use of hydrogel has then been an observation in a significant number of studies with forest tree species. A number of reasons for such improvement have been pointed out by distinct groups of researchers. As a start, the application of hydrogel has the potential of improving seedling survival, as it allows roots to grow inside the granules of the polymer, which increases the contact among roots, water and nutrients (THOMAS, 2008). Moreover, it potentially improves the physical and chemical attributes of the substrate employed, enabling better performance of seedling growth at initial stages (NAVROSKI et al., 20I5). Therefore, supplying the hydrogel combined with specific substrates (mainly number 2 ) and fertilizers (mainly A and $B$ ) demonstrated to accelerate the growth of $M$. scabrella seedlings in this study.

Another advantage of the polymer concerns the capacity of retaining water provided by irrigation in greenhouses. The hydrogel demonstrated to retain water for a significantly higher period of time, therefore, reducing the mortality of seedlings of $E$. 
TABLE 6 Summary of quality indexes for Mimosa scabrella seedlings under distinct treatment-combinations (use of hydrogel $\mathrm{x}$ substrate $x$ fertilizer).

\begin{tabular}{|c|c|c|c|c|c|c|c|c|c|c|c|}
\hline \multirow[t]{2}{*}{ Variable } & \multirow[t]{2}{*}{$\mathrm{S}$} & \multicolumn{4}{|c|}{ Fertilizer - No hydrogel } & \multicolumn{6}{|c|}{ Fertilizer - With hydrogel } \\
\hline & & $A$ & B & C & D & Mean & $A$ & B & C & D & Mean \\
\hline \multirow[t]{4}{*}{$\mathrm{H} / \mathrm{d}$} & I & 10.2 & 10.7 & 9.1 & 9.6 & $9.9 \mathrm{AB}$ & $13.1 \mathrm{aA}$ & $10.4 \mathrm{bB}$ & $11.2 \mathrm{abA}$ & $10.9 \mathrm{abA}$ & 11.4 \\
\hline & 2 & 12.1 & 10.4 & 9.9 & 10.5 & I0.7 A & $12.1 \mathrm{abA}$ & $13.4 \mathrm{aA}$ & I0.2 bAB & $9.7 \mathrm{bA}$ & 11.3 \\
\hline & 3 & 10.8 & 10 & 8.1 & 7.9 & $9.2 \mathrm{~B}$ & $13.3 \mathrm{aA}$ & $13.3 \mathrm{aA}$ & $8.4 \mathrm{bB}$ & $11.0 \mathrm{aA}$ & 11.5 \\
\hline & Mean & $11.0 \mathrm{a}$ & $10.3 \mathrm{ab}$ & $9.0 \mathrm{~b}$ & $9.335 \mathrm{ab}$ & - & 12.8 & 12.4 & 9.9 & 10.6 & - \\
\hline \multirow[t]{4}{*}{ PSDW (\%) } & I & 63.2 & 71.2 & 45.5 & 49.2 & $57.3 \mathrm{~A}$ & 69 & 74.1 & 70.3 & 61.9 & $68.8 \mathrm{~A}$ \\
\hline & 2 & 51 & 70.1 & 61.2 & 42.7 & $56.3 \mathrm{~A}$ & 73.8 & 74.2 & 62.9 & 68.9 & $69.9 \mathrm{~A}$ \\
\hline & 3 & 64.5 & 68.9 & 48.8 & 34.7 & $54.2 \mathrm{~A}$ & 62.7 & 61.8 & 49 & 59.9 & $58.3 \mathrm{~B}$ \\
\hline & Mean & $59.6 \mathrm{ab}$ & $70.1 \mathrm{a}$ & $51.8 \mathrm{bc}$ & $42.2 c$ & - & $68.5 \mathrm{~A}$ & $70.034 \mathrm{~A}$ & $60.7 \mathrm{~A}$ & $63.6 \mathrm{~A}$ & - \\
\hline \multirow[t]{4}{*}{ PRDW (\%) } & I & 36.8 & 28.8 & 54.5 & 50.8 & $42.7 \mathrm{IA}$ & 31 & 25.9 & 29.7 & 38.1 & $31.1 \mathrm{~B}$ \\
\hline & 2 & 49 & 29.9 & 38.8 & 57.3 & $43.7 \mathrm{~A}$ & 26.2 & 25.8 & 37.1 & 31.1 & $30.0 \mathrm{~B}$ \\
\hline & 3 & 35.5 bc & $31.1 \mathrm{c}$ & $51.2 \mathrm{ab}$ & $65.3 \mathrm{a}$ & $45.8 \mathrm{~A}$ & 37.3 & 38.2 & 51 & 40.1 & 4I.7A \\
\hline & Mean & 40.414 & 29.908 & 48.164 & 57.8 & - & $31.5 \mathrm{~A}$ & $29.9 \mathrm{~A}$ & $39.3 \mathrm{~A}$ & $36.4 \mathrm{~A}$ & - \\
\hline \multirow[t]{4}{*}{ DQI } & I & 0.011 & 0.016 & 0.012 & 0.024 & $0.016 \mathrm{~A}$ & $0.022 \mathrm{aB}$ & $0.039 \mathrm{aA}$ & $0.024 \mathrm{aA}$ & $0.029 \mathrm{aA}$ & 0.029 \\
\hline & 2 & 0.024 & 0.018 & 0.028 & 0.032 & $0.026 \mathrm{~A}$ & $0.037 \mathrm{aB}$ & $0.054 \mathrm{aA}$ & $0.04 \mathrm{I} \mathrm{A}$ & $0.023 \mathrm{aA}$ & 0.039 \\
\hline & 3 & 0.035 & 0.021 & 0.018 & 0.079 & $0.038 \mathrm{~A}$ & $0.085 \mathrm{aA}$ & $0.048 \mathrm{abA}$ & $0.012 \mathrm{bA}$ & $0.007 \mathrm{bA}$ & 0.038 \\
\hline & Mean & $0.024 \mathrm{a}$ & $0.018 \mathrm{a}$ & $0.019 a$ & $0.045 \mathrm{a}$ & - & 0.048 & 0.047 & 0.026 & 0.02 & - \\
\hline
\end{tabular}

Substrates: I - 70\% Turfa Fértil (TF), 10\% Vermiculite (VM) and 20\% pine bark (PB); 2 - 40\% TF, 40\% VM, 20\% PB; and 3 - 10\% TF, 70\% VM and 20\% PB. Fertilizers: A - Slow release formula at 6 g.L-I; B - Conventional NPK (05-20-10) at 6 g.L-I; C - Compost of simple superphosphate; D - Control, without fertilizer. $\mathrm{H} / \mathrm{d}(\mathrm{cm} / \mathrm{mm})$ : proportion of plant height to root collar diameter; PSDW (\%): proportion of the shoot dry weight to the total; PRDW (\%): proportion of the root dry weight to the total; DQI: Dickson quality index. Different capital letters indicate significant differences $(P<0.05)$ in columns, while different lowercase letters indicated differences in lines.

urophylla (BUZETTO et al., 2002). By extension of this advantage, significant line of evidence has shown that hydrogel has the potential of delaying the symptoms caused by water deficit in seedlings, such as of $E$. dunnii (NAVROSKI et al., 20I4) and $E$. benthamii (FELIPPE et al., 20I6).

An additional positive effect of the use of hydrogel is the potential reduction of the use of fertilizers in nurseries, as demonstrated with $C$. citriodora seedlings. Hydrogel not only improved the seedlings quality, but also diminished the requirement of fertilizers in at least 20\% (BERNARDI et al., 20I2). It has a direct impact on the reduction of costs to producers, which will then require lower amounts of fertilizers for achieving their final products with the same or even higher qualities.

\section{The most suitable combination of substrate and fertilizer for M. scabrella}

Evidently, the use of hydrogel alone would not have implicated in a distinguished quality of the seedlings if it were not combined with an appropriate substrate and fertilizer. The substrate represents a critical role in the development of the seedlings and needs to attend some general criteria such as an adequate porosity, the capacity of retaining water and an adequate proportion of the sizes among the substrate particles (GONÇALVES et al., 2000; GUERRINI and TRIGUEIRO, 2004).
In general, the substrate 2 combined with hydrogel and fertilizers $A$ and $B$ resulted in the best results of growth and quality of the seedlings. The substrate 2 (composed by $40 \%$ of the organic compound, $40 \%$ of vermiculite and $20 \%$ of pinus bark), probably, presented higher equilibrium between the macro and microporosity than the substrates I (70\% of organic compound, 10 $\%$ of vermiculite and $20 \%$ of pinus bark) and 3 (10\% of organic compound, $70 \%$ of vermiculite and $20 \%$ of pinus bark). Normally, the recommended macroporosity for producing seedlings of forest tree species is between 35 and $45 \%$ (GONÇALVES and POGGIANI, 1996). As a result, the microporosity should be between 45 and $55 \%$. Vermiculite generally has around $44 \%$ of macro and $46 \%$ of microporosity (GONÇALVES and POGGIANI, 1996).

The capacity of retaining water was significantly altered by the addition of hydrogel, as previously discussed. For forest tree species, it has been indicated that the maximum capacity of retaining water should be between 25 and $30 \mathrm{~mL} . \mathrm{cm}^{-3}$ and vermiculite alone has a retention capacity of approximately $23 \mathrm{~mL} . \mathrm{cm}^{-3}$ (GONÇALVES and POGGIANI, 1996). The organic compost used in this study also has a high water retention capacity (57\%). Therefore, the combination of the substrate with the hydrogel was important for determining better establishment, growth and quality of the seedlings.

The fertilizers A and B provided the best performance of the seedlings, but especially for those 
TABLE 7 Pearson correlation coefficients among biomass and growth variables of Mimosa scabrella seedlings.

\begin{tabular}{|c|c|c|c|c|c|c|c|c|c|c|c|c|c|}
\hline & SFW & RFW & SDW & RDW & TDW & SM & RM & $\mathrm{H}$ & D & $H / D$ & PSDW & PRDW & DQI \\
\hline SFW & - & 0.754 & 0.986 & 0.678 & -0.022 & 0.290 & 0.929 & 0.914 & 0.106 & 0.142 & -0.142 & 0.899 & 0.605 \\
\hline RFW & 0.754 & - & 0.778 & 0.937 & 0.267 & 0.385 & 0.671 & 0.704 & 0.021 & -0.390 & 0.390 & 0.922 & 0.766 \\
\hline SDW & 0.986 & 0.778 & - & 0.726 & 0.098 & 0.338 & 0.919 & 0.903 & 0.088 & 0.095 & -0.095 & 0.931 & 0.641 \\
\hline RDW & 0.678 & 0.937 & 0.726 & - & 0.314 & 0.565 & 0.594 & 0.614 & 0.017 & -0.433 & 0.433 & 0.926 & 0.776 \\
\hline TDW & -0.022 & 0.267 & 0.098 & 0.314 & - & 0.356 & 0.022 & 0.025 & -0.159 & -0.505 & 0.505 & 0.220 & 0.289 \\
\hline SM & 0.290 & 0.385 & 0.338 & 0.565 & 0.356 & - & 0.306 & 0.304 & -0.007 & -0.515 & 0.515 & 0.484 & 0.455 \\
\hline $\mathrm{RM}$ & 0.929 & $0.67 \mid$ & 0.919 & 0.594 & 0.022 & 0.306 & - & 0.925 & 0.154 & 0.154 & -0.154 & 0.817 & 0.453 \\
\hline $\mathrm{H}$ & 0.914 & 0.704 & 0.903 & 0.614 & 0.025 & 0.304 & 0.925 & - & 0.077 & 0.090 & -0.090 & 0.819 & 0.577 \\
\hline D & 0.106 & 0.021 & 0.088 & 0.017 & -0.159 & -0.007 & 0.154 & 0.077 & - & 0.113 & -0.113 & 0.058 & -0.081 \\
\hline$H / d$ & 0.142 & -0.390 & 0.095 & -0.433 & -0.505 & -0.515 & 0.154 & 0.090 & 0.113 & - & -1.000 & -0.178 & -0.354 \\
\hline PSDW & -0.142 & 0.390 & -0.095 & 0.433 & 0.505 & 0.515 & -0.154 & -0.090 & -0.113 & -1.000 & - & 0.178 & 0.354 \\
\hline PRDW & 0.899 & 0.922 & 0.931 & 0.926 & 0.220 & 0.484 & 0.817 & 0.819 & 0.058 & -0.178 & 0.178 & - & 0.761 \\
\hline DQI & 0.605 & 0.766 & 0.641 & 0.776 & 0.289 & 0.455 & 0.453 & 0.577 & -0.081 & -0.354 & 0.354 & 0.761 & - \\
\hline
\end{tabular}

SFW (g): shoot fresh weight; RFW (g): root fresh weight; SDW (g): shoot dry weight; RDW (g): root dry weight; TDW (g): total dry weight; SM (\%): shoot moisture content; RM (\%): root moisture content; $\mathrm{H}(\mathrm{cm})$ : plant height; $\mathrm{d}(\mathrm{mm})$ : root collar diameter; $\mathrm{H} / \mathrm{d}(\mathrm{cm} / \mathrm{mm})$ : proportion of plant height to root collar diameter; PSDW (\%): proportion of the shoot dry weight to the total; PRDW (\%): proportion of the root dry weight to the total; DQI: Dickson quality index.

with substrates that received hydrogel in the mixture.

The hydrogel promoted better absorption of the nutrients (THOMAS, 2008). As fertilizers $A$ and $B$ constituted sources of $\mathrm{N}, \mathrm{P}$ and $\mathrm{K}$, their superior effects in the plant development should be expected when compared with $C$ (only $\mathrm{P}$ and $\mathrm{K}$ ) and $\mathrm{D}$ (without fertilizer). Moreover, although bracatinga is a Fabaceae member with natural capacity of fixating $\mathrm{N}$, the supplementation with a $\mathrm{N}$-based fertilized also improved the performance of the species.

\section{CONCLUSIONS}

The use of hydrogel promoted significant improvement in the growth of $M$. scabrella seedlings grown in greenhouse conditions, as demonstrated by the increase in plant height, collar diameter and plant biomass. As a result, significantly higher quality of the seedlings were obtained, as indicated from indexes such as the Dickson quality index.

The combination of the organic compound and vermiculite in equilibrated proportions ( $40 \%$ each) aid by pinus bark (20\%) (substrate 2) conferred the best substrate for growing the seedlings of $M$. scabrella. Combining this substrate with fertilizers composed by NPK, of slow release $(A)$ or the traditional NPK $(B)$, implicated in the best performance of growth of the seedlings.

Therefore, the combined use of hydrogel, substrate 2 and fertilizers A or B resulted in the best performances of $M$. scabrella seedlings grown in this study. Further assessment of the dosages of each factor, however, is recommended to determine the optimal conditions and quantities.

\section{REFERENCES}

ALVARES, C. A.; STAPE, J. L.; SENTELHAS, P. C.; DE MORAES, G.; LEONARDO, J.; SPAROVEK, G. Köppen's climate classification map for Brazil. Meteorologische Zeitschrift, v. 22, n. 6, p. 7II-728, 2013.

BARAZETTI, V. M.; SCCOTI, M. S. V. Quebra de dormência e tipos de substrato para avaliação da qualidade fisiológica de um lote de sementes de bracatinga (Mimosa scabrella Bentham). Unoesc \& CiênciaACET, v. I, n. I, p. 69-76, 2010.

BERNARDI, M. R.; SPEROTTO-JUNIOR, M.; DANIEL, O.; VITORINO, A. C. T. Crescimento de mudas de Corymbia citriodora em função do uso de hidrogel e adubação. Cerne, v. I8, n. I, 2012.

BORSATO, D. M.; PRUDENTE, A. S.; DOLL-BOSCARDIN, P. M.; BORSATO, A. V. ; LUZ, C. F.; MAIA, B. H.; CABRINI, D. A.; OTUKI, M. F.; MIGUEL, M. D.; FARAGO, P. V.; MIGUEL, O. G. Topical anti-inflammatory activity of a monofloral honey of Mimosa scabrella provided by Melipona marginata during winter in Southern Brazil. Journal of Medicinal Food, v. 17, n. 7, p. 817-825, 2014.

BUZETTO, F. A.; BIZON, J. M. C.; SEIXAS, F. Avaliação de um polímero adsorvente a base de acrilamida no fornecimento de água no fornecimento de água em mudas de Eucalyptus Urophylla em pós-plantio. Piracicaba: IPEF, 2002. 8p. Circular Técnica IPEF, n. 195.

CARPANEZZI, A. A.; LAURENT, J. M. E. Manual técnico da bracatinga (Mimosa scabrella Benth). Embrapa Florestas-Documentos (INFOTECA-E), 1988. 70 p.

CARPANEZZI, A. A.; PAGANO, S. N.; BAGGIO, A. J. Banco de sementes de bracatinga em povoamentos do sistema agroflorestal tradicional de cultivo. Boletim de Pesquisa Florestal, v. 35, p. 3-19, 1997. 
DICKSON, A.; LEAF, A. L.; HOSNER, J. F. Quality appraisal of white spruce and white pine seedling stock in nurseries. The Forestry Chronicle, v. 36, n. I, p. 10-13, 1960.

FELIPPE, D.; NAVROSKI, M. C.; SAMPIETRO, J. A.; FRIGOTTO, T.; ALBUQUERQUE, J. A.; MOTA, C. S.; PEREIRA, M. O. Efeito do hidrogel no crescimento de mudas de Eucalyptus benthamii submetidas a diferentes frequências de irrigação. Floresta, v. 46, n. 2, 215-225, 2016.

GOMES, J. M.; COUTO, L.; LEITE, H. C.; XAVIER, A.; GARCIA, S. L. R. Parâmetros morfológicos na avaliação de qualidade de mudas de Eucalyptus grandis. Revista Árvore, v. 26, n. 6, p. 655-664. 2002.

GONÇALVES, J. L. M.; POGGIANI, F. Substrato para produção de mudas. In: Congresso Latino Americano de Ciência do Solo, 13., 1996, Águas de Lindóia. Anais. Águas de Lidóia: SBCS/SLCS, 1996.

GONÇALVES, J. L. M.; SANTARELI, E. G.; MORAES NETO, S. P.; MANARA, M. P. Produção de mudas de espécies nativas: substrato, nutrição, sombreamento e fertilização. In: GONÇALVES, J. L. M.; BENEDETTI, V. (Ed.). Nutrição e fertilização florestal. Piracicaba: IPEF, 2000. p.309-350.

HAMMER, Ř; HARPER, D. A. T.; RYAN, P. D. PAST: Paleontological Statistics Software Package for Education and Data Analysis-Palaeontol. Electron. 4: 9p. 2001.

KRATZ, D.; WENDLING, I. Produção de mudas de Eucalyptus dunnii em substratos renováveis. Floresta, Curitiba, v. 43, n. I, p. I25-136, 2013.

LORENZI, H. Árvores brasileiras: manual de identificação e cultivo de plantas arbóreas do Brasil, v. I, 4.ed. Nova Odessa, SP: Instituto Plantarum, 2002, p.384.

MAZUCHOWSKI, J. Z.; RECH, T. D.; TORESAN, L. Bracatinga: Cultivo, manejo e usos da espécie. Epagri: Florianópolis, 364p. 2014.

MEWS, C. L.; SOUSA, J. R. L. D.; AZEVEDO, G. T. D. O. S.; SOUZA, A. M. Efeito do hidrogel e ureia na produção de mudas de Handroanthus ochraceus (Cham.) Mattos. Floresta e Ambiente, v. 22., n. I, p. 107-I 16, 2015.
NAVROSKI, M. C.; ARAUJO, M. M.; da SILVA CUNHA, F; BERGHETTI, A. L. P., PEREIRA, M. de O. Influência do polímero hidroretentor na sobrevivência de mudas de Eucalyptus dunnii sob diferentes manejos hídricos. Nativa, v. 2, n. 2, p. 108-II3, 2014 .

NAVROSKI, M. C.; ARAUJO, M. M.; FIOR, C. S.; CUNHA, F. D. S.; BERGHETTI, Á. L. P.; PEREIRA, M. O. Uso de hidrogel possibilita redução da irrigação e melhora o crescimento inicial de mudas de Eucalyptus dunnii Maiden. Scientia Forestalis, v. 43, n. 106, p. 467-476, 2015.

CÔRREA DA ROSA, F., REINIGER, R. S; GOLLE, D. P.; BRIÃOMUNIZ, M. F.; RITTER-CURTI, A. Superação da dormência e germinação in vitro de sementes de bracatinga (Mimosa scabrella Bentham). Semina: Ciências Agrárias, v. 33, n. 3, p. $1021-1026,2012$.

FERREIRA, E. B.; CAVALCANTI, P. P.; NOGUEIRA, D. A. ExpDes: experimental designs pacakge. Version I.I. 2. 2013.

ROTTA, E.; Oliveira, Y. M. M. Área de distribuição natural da bracatinga (Mimosa scabrella Benth.). In: Bracatinga: uma alternativa para reflorestamento. Embrapa: Curitiba, 198 p. 198I.

SARVAŠ, M.; PAVLENDA, P.; TAKÁČOVÁ, E. Effect of hydrogel application on survival and growth of pine seedlings in reclamations. Journal of Forest Science, v. 53, n. 5, p. 204-209, 2007.

SILVA, L. J. da. Package “laercio”. 2015.

STÜPP, Â. M., NAVROSKI, M. C., FELIPPE, D., KNIESS, D. D. C., AMANCIO, J. C., SILVA, M. A., PEREIRA, M. O. Crescimento de mudas de Mimosa scabrella Benth em função de diferentes tamanhos de recipientes e doses de fertilizante. Revista Ecologia e Nutrição FlorestalENFLO, v. 3, n. 2, p. 40-47, 2015.

THOMAS, D. S. Hydrogel applied to the root plug of subtropical eucalypt seedlings halves transplant death following planting. Forest Ecology and Management, v.255, n.3-4, p.|305-|3|4, 2008.

WALKER, C.; ARAÚJO, M. M.; MACIEL, C. G.; MARCUZZO, S. B. Viveiro florestal: evolução tecnológica e legalização. Revista Verde de Agroecologia e Desenvolvimento Sustentável, v. 6, n. 5, p. 8-14, 2012. 